\title{
Power dynamics, gender relations and decision-making regarding induced abortion among university students in Nigeria John Lekan OYEFARA
}

\author{
Department of Sociology, Faculty of Social Sciences \\ University of Lagos \\ Akoka, Yaba, Lagos, Nigeria. \\ loyefara@unilag.edu.ng, oyefara@yahoo.com
}

\begin{abstract}
This study investigates the effects of gender and power relations on decision-making regarding induced abortion among undergraduate students in Nigeria. The qualitative in-depth interview method of data collection was utilised to elicit data on the objectives of the study. Findings of the study reveal four dimensions of gender and power relations that have significant impact on decision-making regarding induced abortion in the study location. The four essential forms of gender and power relations identified are: i.) Male-female power relations, ii.) Parent-child power relations, iii.) Significant order and power relations among peers, and iv.) Lecturer-student power relations. These four typologies of gender and power relations among other things promote a detrimental culture of clandestine and unsafe induced abortion among single young undergraduate students in Nigeria. Based on the findings of the study, there is a need to strengthen the existing structure that promotes gender equality in the country. In addition, young female students that are sexually active should be empowered to adopt efficient and effective contraception. Furthermore, there is a need to build the capacity of Nigerian female undergraduate students especially in the areas of self-dignity and self-esteem in order for them to take right decisions whenever an unwanted pregnancy occurs.
\end{abstract}

Key words: Power Dynamics, Gender Relations, Decision-making, Induced Abortion, Nigeria.

\section{Introduction}

Globally, issues related to abortion were taken as moral and religious debates for several decades in the past. For the first time in history however, abortion became recognised as a public health problem during the 1994 International Conference on Population and Development (ICPD) and the world's attention became drawn to the dire need to address the issue with the seriousness it truly deserves. Hence, the cost of morbidity and mortality from abortion complications is more manifested amongst countries of the developing world where low socio-economic conditions, legal restrictions, and an overall poor development of the health care delivery system prevail.

According to Post Abortion Care Consortium [PAC] (2002), morbidity and mortality due to unsafe abortion continue to pose a serious global threat to women's health and lives. It is estimated that worldwide, every year, almost 20 million unsafe abortions take place and 80,000 women die from complications following unsafe abortion. In Nigeria it is estimated that approximately 760,000 abortions are performed annually. Non-physicians are known to perform up to $60 \%$ of these abortions, while as high as $87 \%$ are performed in private health facilities (Bankole et al., 20I5). It is believed that one in every I0 Nigerian women has had an induced abortion. This however varies in proportion amongst different population groups depending on the socio-economic status, religion, marital status, as well as the fertility status of the women (Bankole et al., 20I5, Oyefara, 2016, Sedgh et al., 2016). Access to contraceptive methods to prevent unwanted pregnancy and a continuum of post-abortion care that includes comprehensive counseling, access to contraception and family planning to prevent future unwanted pregnancies or to practice birth spacing, and access to reproductive and other health services, are all essential means of preventing unsafe abortion and improving the lives of women and their families. Another study shows an estimate that 2 million to 4.4 million adolescents have unsafe abortions each year, accounting for an estimated $14 \%$ of the unsafe abortion that are performed in all developing countries (Olukoya et al., 200I, WHO, 2004). Adolescents are more likely than older women to face significant obstacles to obtaining a safe abortion (Olukoya et al., $200 \mathrm{I}$ ), and $38 \%$ to $68 \%$ of women 
admitted to a hospital for abortion complications in countries where abortion is legally restricted are under age 20 (Bankole, Singh \& Hass, 1999). Thus, in societies where abortion is legally restricted or access to such services is limited, women with an unwanted pregnancy often resort to unsafe abortion and subsequently require urgent medical attention to treat complications. Women may also suffer incomplete spontaneous abortions (miscarriages) or complications from a safe abortion that requires medical attention. It is imperative to note that previous studies on induced abortion in Nigeria focused majorly on its incidence, determinants, consequences and legal context (Alubo, 1990, Makinwa-Adebusoye, Singh \& Audam, 1997, SuleOdu, Olatunji \& Akindele, 2002, Aniekwu, 2003, Bankole et al., 2004, Bankole et al. 2006, Biddlecom et al., 2009, Bankole et al., 2015, Oyefara, 2012, 2016, Sedgh et al., 2016). Little or no attention has been paid to the effect of gender dynamics and power relations in decision-making regarding induced abortion in the country, which underscores the need for this study.

In 'History of Sexuality', Foucault (1998) argued that medicine deals more with the morality of sexuality than with the science of sexuality. In theory, medicine presents itself as a tool for discovering the hidden facts of life but in practice, it is designed to control human anatomy and sexuality. The essence of medicine, psychology, psychiatry and other sciences is not to promote the world but to substitute in disguise the religious confessions that preceded it. Foucault used two critical knowledge types to expose Western science; I. Anatomo-politics, which is the power to discipline the human body 2. Bio-power, which is the power to control and regulate population growth, health, life expectancy, maternal mortality, etc.

In power relations, Foucault believed that domination is the essence of power but that the rulers too are controlled by certain powers in society. Foucault believed that power is not stable because knowledge and technology are not stable. People with the dominant knowledge in society are more likely to dominate others, and determine the direction of their decisions. This model among others is relevant to our understanding of the gender dynamics and power relations in decision-making regarding induced abortion among undergraduates in Nigeria. Consequently, this paper critically examines the role of power, authority, and superiority of male sexual partners, parents, peers or lecturers on decision-making regarding induced abortion by undergraduate students in Nigeria.

\section{Theoretical Orientation of the Study}

Analysis and interpretation of various data generated in this study were anchored on the multi-dimensional orientation of sociological theories of social power. The core assumption of these models as posited by Haralambos \& Heald (1980:24) is that all human societies from the simplest to the most complex have some form of social inequality. Thus, power and prestige are unequally distributed between individuals and social groups. In many societies there are also marked differences in the distribution of wealth. According to these scholars, power refers to the degree to which individuals or groups can impose their will on others, with or without the consent of those others. Prestige relates to the amount of esteem or honour associated with social positions, qualities of individuals and styles of life. Wealth refers to material possessions defined as valuable in particular societies.

Various models of social power explicate the unequal distribution of power, prestige and wealth in society. Scholars in the literature did strive to explain the differences between social inequality and social stratification. As explained by the experts, the term social inequality simply refers to the existence of socially created inequalities and the fact that social stratification is a particular form of social inequality. Inherent in social stratification and inequality is the hierarchical arrangement of positions in a significant order with the associated power/authority to function effectively in a social position. As noted by Haralambos \& Heald (1980:98) "sociologists often distinguish between two forms of power, authority and coercion. Authority is that form of power which is accepted as legitimate, that is right and just, and therefore obeyed on that basis. Coercion is that form of power which is not regarded as legitimate by those subject to it." It is imperative to note that the distinction between authority and coercion is not as clear-cut as the two definitions suggest. Thus, it has often been argued that both forms of power are based ultimately on physical force and those who enforce the law are able to resort to physical force whether their power is regarded as legitimate or not.

In order to understand the complex nature of power in the society, sociologists distinguish between the following three essential forms: $i$. power as domination - a social relationship in which one social actor is seen as having total control over the actions of another individual; ii. power as coercion - a social relationship in which one social actor relies upon various kinds of sanctions, such as physical force or threat of economic deprivation, to achieve the compliance of another; iii. power as influence - a social relationship in which one social actor seeks to achieve a desired social outcome through argument or through the promise of various material or 
symbolic rewards. It is imperative to mention that many power relationships involve a combination of these various forms.

In order to explain the nature and dynamics of power relations in society in relation to induced abortion, three theoretical perspectives were adopted in this study. These are the functionalist perspective, the Marxian perspective and Michel Foucault's theory of power-is-everywhere. The functionalists believe in a variable-sum concept of power. To Talcott Parsons, one of the proponents of the functionalist perspective, power is something possessed by society as a whole and it is a generalised facility or resource in the society. Specifically, power is the capacity to mobilise the resources of the society for the attainment of goals for which a general "public" commitment has been made. Thus, according to a functionalist perspective, power is a societal resource held in trust and directed by those in authority for the benefit of all.

In contrast, the Marxian perspective rejects the functionalist perspective and argues that those who hold power do so at the expense of others. This perspective is sometimes known as a "constant-sum" concept of power because it suggests firstly, that there is a fixed amount of power and therefore if some hold power, others do not and secondly, the fact that the power holders will tend to use power to further their own interests. It can be adduced from this perspective that power is used to further the sectional interests of the power holders which are in conflict with the interests of those subject to that power. Thus, this perspective sees power as a resource used mainly for the exploitation and oppression of some by others.

Michel Foucault's theory of power is a radical departure from previous modes of conceiving power and cannot be easily integrated with previous ideas, as the author argued that power is diffuse rather than concentrated, embodied and enacted rather than possessed, discursive rather than purely coercive, and constitutes agents rather than being deployed (Gaventa 2003: I). Foucault challenges the idea that power is wielded by people or groups by way of "episodic" or "sovereign" acts of domination or coercion, seeing it instead as dispersed and pervasive. "Power is everywhere" and "comes from everywhere" so in this sense, it is neither an agency nor a structure (Foucault, 1998: 63). Instead it is a kind of "metapower" or "regime of truth" that pervades society, and which is in constant flux and negotiation. Foucault uses the term "power/knowledge" to signify that power is constituted through accepted forms of knowledge, scientific understanding and "truth". He explained that "power is everywhere", diffused and embodied http://aps.journals.ac.za in discourse, knowledge and "regimes of truth" (Foucault, 199I, Rabinow, 199I).

The key point about Foucault's approach to power is that it transcends politics and sees power as an everyday, socialised and embodied phenomenon that can be seen everywhere and at all levels of human relations and interactions. In his initial books, what Foucault explores is how the creation of modern disciplines, with their principles of order and control, tends to "disindividualise" power, making it seem as if power inheres in the prison, the school, the factory, and so on. However, in his later work, Foucault makes clear that power ultimately does inhere in individuals, including those that are surveilled or punished. Consequently, power always entails a set of actions performed upon another person's actions and reactions. Foucault posited that in itself the exercise of power is always a way of acting upon an acting subject or acting subjects by virtue of their acting or being capable of action. He therefore turns in his later work to the concept of "government" in order to explain how power functions.

"Government" did not refer only to political structures or to the management of states; rather it designated the way in which the conduct of individuals or of groups might be directed: the government of children, of souls, of communities, of families, of the sick. Thus, since "Power is everywhere" and "comes from everywhere", we all experience power in every aspect of our lives. Teachers have power over students, doctors over patients, parents over children, husbands over wives, governments over citizens and the fate of whole societies. The synthesis of these three perspectives was used to explain the dynamics of decision-making regarding induced abortion among university students in Nigeria.

\section{Data and methods}

The study employed an in-depth interview research method in order to generate qualitative data on the topic of the study. The study population comprised both male and female undergraduate students of University of Lagos. To be eligible, the respondent must have procured at least one induced abortion personally. Thus male respondents are those ones that have procured induced abortion for their female partners, while the female respondents are ladies that have procured abortion personally before. Using purposive and snowballing sampling methods, a total of 40 ( 24 female and 16 male) students were selected and interviewed for the study.

One research instrument was developed to elicit data from the respondents in the study which is an indepth interview guide. The guide used during the 
study was designed in such a way that adequate information was collected on the research questions with a view to actualising the purpose and objectives of the study. The fieldwork activities of the study were carried out between September and December 20I4. Ten (10) research assistants were engaged to collect the data ( 5 males and 5 females). In order to enhance the quality of data generated in the study, female research assistants interviewed female respondents, while male research assistants interviewed male respondents.

Data cleaning, processing, and analysis were done manually using a thematic framework approach. This process involves verbatim transcription of returned tapes by the research assistants after the data collection. The transcripts were screened, edited, and double-checked independently by the principal investigator severally for internal consistency, accuracy, and the elimination of possible spurious responses before further processing of the data. The second phase of the analysis involved coding, sorting, and theme identification. The coding log was developed based on the central objectives of the study, the research instrument, and various responses elicited from the respondents. This process led to the development of a final list of themes and sub-themes that are germane to the greater understanding of the topic of the research. After coding, sorting, and theme identification, the generated qualitative data were analysed using the content analysis method. Considering the medical and social implications of the topic of the study on the respondents, informed written consent was taken from all the respondents after full explanation of the nature, purpose, and all procedures used for the study. Confidentiality was maintained throughout the study period. Furthermore, respondents were completely anonymous in relation to their responses.

\section{Results}

\section{Background Profile of Respondents}

A total of forty (40) respondents were sampled and interviewed in the study as noted in the method section. It is important to note that three-fifth of the respondents were females while, the remaining twofifth were males. The male respondents had procured induced abortion for their female partners, while the female respondents had procured induced abortion personally for themselves. The respondents originated from different parts of Nigeria: north, east, west and south. This is not unexpected as Lagos has been described as the socio-economic nerve centre and melting point of all ethnic groups in Nigeria, and the University of Lagos, the study location, has been acknowledged to be the University of First Choice in Nigeria. The overall age distribution was symmetrical. The mean age of the respondents was 22. I years; the median age was 22 years. The age distribution was multimodal with the ages 20, 22, 24 years. Christianity and Islam are the two major religions in the country, however majority of the respondents professed Christianity. The respondents were undergraduate students of various faculties in the institution during the 20/3/14 academic session. Furthermore, majority of the respondents were single as at the time of the study. Detailed available socio-demographic profile of male and female respondents of the study can be seen in Table I and Table 2 respectively.

Table 1: Socio-Demographic Characteristics of Male Respondents

\begin{tabular}{|c|c|c|c|c|c|c|c|c|}
\hline $\mathbf{S} / \mathbf{N}$ & Sex & $\begin{array}{l}\text { Age } \\
\text { (Years) }\end{array}$ & $\begin{array}{l}\text { Marital } \\
\text { Status }\end{array}$ & Religion & $\begin{array}{l}\text { Ethnic } \\
\text { Group }\end{array}$ & Faculty & Department & Level \\
\hline \multicolumn{9}{|c|}{ Males who have procured induced abortion for their partners } \\
\hline 1 & Male & 24 & Married & Christianity & Yoruba & Social Sciences & Sociology & 400 \\
\hline 2 & Male & 28 & Single & Christianity & Tiv & Engineering & Elect./Engineering & 300 \\
\hline 3 & Male & 30 & Single & Islam & Yoruba & Social Sciences & Economics & 400 \\
\hline 4 & Male & 26 & Single & Christianity & Igbo & Social Sciences & Sociology & 500 \\
\hline 5 & Male & 31 & Single & Christianity & Edo & Engineering & Civil Engineering & 400 \\
\hline 6 & Male & 28 & Single & Christianity & Yoruba & Environmental Sciences & $\begin{array}{l}\text { Urban \& Regional } \\
\text { Planning }\end{array}$ & 500 \\
\hline 7 & Male & 26 & Single & Christianity & Igbo & Social Sciences & Political Science & 300 \\
\hline 8 & Male & 24 & Single & Christianity & Yoruba & Social Sciences & Psychology & 300 \\
\hline 9 & Male & 25 & Single & Islam & Yoruba & Arts & English & 200 \\
\hline 10 & Male & 21 & Single & Christianity & Igbo & Sciences & Zoology & 300 \\
\hline 11 & Male & 28 & Single & Islam & Igbo & Business Administration & Accounting & 300 \\
\hline 12 & Male & 22 & Single & Christianity & Yoruba & Sciences & Chemistry & 400 \\
\hline 13 & Male & 22 & Single & Christianity & Yoruba & Social Sciences & Sociology & 400 \\
\hline 14 & Male & 24 & Single & Christianity & Yoruba & Social Sciences & Sociology & 400 \\
\hline 15 & Male & 24 & Single & Islam & Hausa & Social Sciences & Sociology & 400 \\
\hline
\end{tabular}




\begin{tabular}{|l|l|l|l|l|l|l|l|l|}
\hline 16 & Male & 23 & Single & Christianity & Yoruba & Social Sciences & Sociology & 400 \\
\hline
\end{tabular}

Table 2: Socio-Demographic Characteristics of Female Respondents

\begin{tabular}{|c|c|c|c|c|c|c|c|c|}
\hline $\mathbf{S} / \mathbf{N}$ & Sex & $\begin{array}{l}\text { Age } \\
\text { (Years) }\end{array}$ & $\begin{array}{l}\text { Marital } \\
\text { Status }\end{array}$ & Religion & $\begin{array}{l}\text { Ethnic } \\
\text { Group }\end{array}$ & Faculty & Department & Level \\
\hline \multicolumn{9}{|c|}{ Females who have procured induced abortion } \\
\hline 1 & Female & 21 & Single & Islam & Yoruba & Social Sciences & Sociology & 100 \\
\hline 2 & Female & 23 & Single & Christianity & Igbo & Social Sciences & Psychology & 100 \\
\hline 3 & Female & 21 & Single & Christianity & Yoruba & Education & $\begin{array}{l}\text { Educational } \\
\text { Administration }\end{array}$ & 100 \\
\hline 4 & Female & 29 & Single & Islam & Yoruba & Art & Theatre Art & 300 \\
\hline 5 & Female & 26 & Single & Christianity & Yoruba & Social Sciences & Sociology & 400 \\
\hline 6 & Female & 20 & Single & Christianity & Igbo & Social Sciences & Political Science & 200 \\
\hline 7 & Female & 25 & Single & Christianity & Igbo & Sciences & Chemistry & 300 \\
\hline 8 & Female & 29 & Married & Christianity & Isoko & Social Sciences & Sociology & 400 \\
\hline 9 & Female & 24 & Single & Islam & Yoruba & Social Sciences & $\begin{array}{l}\text { Mass } \\
\text { Communication }\end{array}$ & 200 \\
\hline 10 & Female & 20 & Single & Christianity & Yoruba & Sciences & Mathematics & 400 \\
\hline 11 & Female & 21 & Single & Christianity & Yoruba & Sciences & Marine Science & 200 \\
\hline 12 & Female & 22 & Single & Islam & Yoruba & Sciences & Mathematics & 400 \\
\hline 13 & Female & 23 & Single & Christianity & Yoruba & Business Administration & Finance & 300 \\
\hline 14 & Female & 24 & Single & Christianity & Igbo & Arts & Creative Arts & 200 \\
\hline 15 & Female & 25 & Single & Christianity & & Social Sciences & Sociology & 400 \\
\hline 16 & Female & 28 & Married & Christianity & Igbo & Law & Law & 500 \\
\hline 17 & Female & 30 & Single & Christianity & Yoruba & Social Sciences & $\begin{array}{l}\text { Mass } \\
\text { Communication }\end{array}$ & 400 \\
\hline 18 & Female & 29 & Single & Traditional & Yoruba & Arts & English & 200 \\
\hline 19 & Female & 28 & Single & Christianity & Yoruba & Social Sciences & Sociology & 400 \\
\hline 20 & Female & 23 & Single & Christianity & Yoruba & Social Sciences & Political Science & 300 \\
\hline 21 & Female & 26 & Single & Christianity & Yoruba & Business Administration & $\begin{array}{l}\text { Business } \\
\text { Administration }\end{array}$ & 400 \\
\hline 22 & Female & 23 & Single & Islam & Hausa & Social Sciences & Economics & 200 \\
\hline 23 & Female & 26 & Married & Islam & Yoruba & Sciences & Microbiology & 400 \\
\hline 24 & Female & 21 & Single & Christianity & Igbo & Arts & English & 200 \\
\hline
\end{tabular}

Power Dynamics and Gender Relations in decision-making regarding induced abortion

There are three major decisions to be taken when a young single female undergraduate has an unwanted pregnancy. The first one is the decision to terminate the pregnancy; the second decision is to decide on the method to be adopted in order to terminate the pregnancy, while the third decision is about the place where the abortion will be procured. These three decisions are strongly guided by power dynamics and gender relations. The nature of power relations based on the principles of significant order and control are complex and numerous. In this paper however, the following four dimensions of power relations and significant order were examined and presented: i. Male-female power relations, ii. Parentchild power relations, iii. Significant order power relations among peers, and iv. Lecturer-student power relations. Findings on each of these power relations were presented in the sections in this article that follow respectively.
Male-female power relations and induced abortion decision-making

Patriarchy, a major feature of a traditional African society, is a structure of a set of social relations with a material base which enables men to dominate women. It is a social structure in which power and authority reside with men and such men are accorded headship titles such as breadwinners and heads of homes. This structure invariably generates male-female power relations at home and in the community in which men exercise and enjoy leadership power and authority over women. This male-female power relation has a significant impact on decision-making regarding induced abortion among undergraduate students in Nigeria. For instance, a 28 year old 400 level female student explained how male-female power relations made her to abort her first pregnancy in the following way:

"One major aspect of our culture is the fact that men are the heads of homes, they are the one to marry the women, and they are the 
breadwinners. All things being equal, they ought to provide for the basic needs of their homes such as accommodation, feeding, clothing and other necessities of life. In such a scenario, they have an absolute power over women. I had my first pregnancy when I was 25 years old which I intended to keep because I was thinking of settling down with a man. However, my boyfriend was not ready to take responsibility for the pregnancy and he insisted that it should be terminated. Initially I resisted his suggestion but on the long run I had to abort the pregnancy since he was not ready to take up the responsibilities of a father and husband. It was a painful experience, but I could not help the situation if he does not accept to be the father of the child."

Another female respondent explained her experience thus:

"I have procured induced abortion for three times and my fiancé was solely responsible for the three pregnancies. I love him and I respect his opinions. He has promised to marry me and we are both working toward the consummation of the nuptial relationship. On each of the three occasions of induced abortion, my fiancé was of the opinion that we are not ready to start to shoulders parenting responsibilities since both of us are still young. Although he is working and I am in school, he thought we have to work hard, save sufficient money and I should finish my university education before we start having children. He is the man and he will be my husband and father of my children. His decision is paramount in our relationship. Once he has decided what we should do, I have to support him. He said the pregnancies should be aborted and he provided the money for induced abortion in each of the three occasions. I have to support him, so I decided to go for the three abortions."

One of the female respondents narrates how power relations between her and her male sexual partner made her to commit an induced abortion. She relates:

"My boyfriend was not ready for the pregnancy, thus he persuaded me to commit the abortion. At first I did not support the idea and I thought having the baby will make our love stronger. But I was wrong. He changed his behaviour completely to the extent that I had no option than to abort the pregnancy."
A male respondent who has procured induced abortion for four of his girlfriends explained what usually guides his decisions on induced abortion. He explained thus:

"The moment I hear about the pregnancy, the next thing that will come to my mind is how the pregnancy will be terminated within the next one to three weeks after when I got the information. I will quickly look for the money and other necessary things that will assist both of us. There is no room for delay and keeping what you know you are not ready for. The decision is to have the pregnancy terminated within a month. It is highly embarrassing for people to see someone's girlfriend pregnant when we have not done a wedding ceremony."

A 31 year old 400 level undergraduate male respondent who arranged for an abortion on the first of his two occasions at 20 years of age explains how he influenced his girlfriend's decision to procure induced abortion. He stated that:

"To me, the thought of an early mothering responsibility on the part of the females and a fathering responsibility on the part of the males is one of the reasons young people go for induced abortion. I had to arrange for an induced abortion for my first girlfriend because both of us were too young to assume parenting responsibilities coupled with the fear of having children out of wedlock. I encouraged her to abort the pregnancy."

A 200 level female student stated that:

"I had to quickly decide on induced abortion because the pregnancy came barely few months after my admission into 100 level in the university. I was just I 7 years old then, too young and single. How can I explain it? The only option available then was to terminate the pregnancy. I informed my sexual partner and he said the better option for us as at then was to abort the pregnancy. He brought the drugs that we used to terminate the pregnancy. I just had to respect his opinion and decision."

The summation of the responses in this section reveals that there exists an unequal power relation between a male and a female in sexual relations. It is also imperative to note that the existing power structure favours males than females. Culturally, in most of African societies, men are the fathers, they are the husbands, breadwinners and heads of 
households; they are the one to marry the women and provide all the basic needs for their homes. This cultural social structure provides a significant order that makes it possible for the male partner to have a significant level of control in sexual relations within and outside the marital context. Consequently, men play significant dominant roles, to a greater extent, about what happens to an unwanted pregnancy of their female sexual partners.

Parent-child power relations and induced abortion decision-making

In addition to male-female power relations, it is important to note that parent-child power relations play a significant role in decision-making regarding induced abortion among young people in Nigeria. Most of the time, the mother, the father or both parents significantly influence their children's decision to procure induced abortion against their initial position not to abort the pregnancy or confused situation of not knowing what to do or the next step to take when an unwanted pregnancy occurs.

For instance, a 26 year old undergraduate lady who has aborted a pregnancy a number of times simply says:

"As we all know, in the contemporary time boyfriend-girlfriend relationships are characterised by both overt and covert sexual intercourse. In the process of having unprotected sex with my boyfriend, I was pregnant and my parents disapproved the pregnancy outrightly on the ground that it occurred outside marriage. To my parents, pregnancy outside marriage is socially wrong and they jointly requested that it should be terminated since I was 19 years old then coupled with the fact that I and my male sexual partner were not socially and economically ready for parenting responsibilities. Thus, I was compelled by my parents' decision and I agreed to abort the pregnancy. It was my mother that took me to the clinic where the pregnancy was terminated."

Another 23 year old female student explained the context in which her first pregnancy was terminated in this way:

"My mother was the first to notice that I was pregnant when I came home for the first semester holiday. My father was not around then because of the nature of his job. My mother quickly took me to her friend and we all visited a doctor in a private hospital and the pregnancy was terminated before my father returned from his trip. My mother did not let my father know about the pregnancy and abortion till today. She said if my father gets to know about the pregnancy and abortion, he will send two of us out of his house. My mother also asked the doctor to give me contraception (oral pills) in order to prevent any other unwanted pregnancy since my father will never tolerate pregnancy before marriage from any of his daughters. If not for my mother's decision, I intended to keep the pregnancy since my sexual partner then was ready to accept the pregnancy and the baby."

A male respondent also narrates how his father's instructions made him to procure induced abortion for his girlfriend. His explanation goes thus:

"My father is very close to me and I share my experience with my girlfriend with him. When my first girlfriend was pregnant and was pestering me about it, it was my father that taught me how to handle the situation. He advised me to have a sincere discussion with my girlfriend about the way to abort the pregnancy since both of us were too young to consider keeping the pregnancy. Both of us were undergraduates and the fact that we have to build our careers and plan for our future was a central priority. I shared his thought with my girlfriend and we both agreed to use the abortive drugs he prescribed and the pregnancy was terminated. Although my mother was not in support of the abortion, my father's decision and counsel made me to procure induced abortion for my girlfriend. Since then, we have procured at least three induced abortion without their knowledge. We are old enough to take care of ourselves."

The above responses reveal the role of parental power in the decision-making process of a young woman/man to procure induced abortion.

Significant order power relations among peers, lecturer-student power relations and induced abortion decision-making

The findings of the study revealed different scenarios around the occurrence of unwanted pregnancy among female undergraduate students in Nigeria. One of such diverse scenarios is a situation where the sexual partner and parents of a lady are not aware about the occurrence of the pregnancy except her friend(s) that serve as her confidant(s). Decisionmaking in such a situation is a function of peer influence. Components or indicators of significant order power relations among peers identified in the study are chronological age, wealth of experience, better financial resources, among others. A 200 level 
female student narrates how her roommate assisted her to abort her first pregnancy when she was in 100 level. According to her:

"I was pregnant in the second semester of my 100 level for a 400 level male student in my department. I was totally confused when the pregnancy occurred; the pregnancy was absolutely unexpected and I did not know what to do at all. It was my roommate who was in 300 level then that noticed my problem and I shared it with her. She laughed and hugged me and told me that I shouldn't worry myself about it. She told me that it is a small thing that can be handled in less than 30 minutes. She took me to a clinic outside the campus and she paid for the procurement of the induced abortion. Few hours later we returned to the campus. I did not tell my boyfriend about the pregnancy and my parents did not know that such a thing happened when I was in 100 level. I really thank my roommate that saved me from the shame of carrying an unwanted pregnancy around at the early stage of my educational career in the university. Now I know how to prevent an unwanted pregnancy courtesy of my friend. She was indeed very kind to me and since then our friendship has been very cordial."

Another female respondent explained how lecturerstudent power relations made her to abort two pregnancies in the course of her study in the university in the following way:

"I entered into a sexual relationship with one of my male lecturers out of too much pressure, harassment and intimidation. There was a time he threatened that I will fail all the courses he was teaching us. At last we started dating each other in order for me to have peace of mind in the university. The relationship has been good for the past three years. However, there was a time I was pregnant for him and I had to abort the pregnancy because he was not ready to marry me. $\mathrm{He}$ compelled me to abort the pregnancy and he threatened me that the management and his family must not know about it. He called and asked me to come to his office for the money to abort the pregnancy. Since I don't want his career to be affected, I had no option than to collect the money and abort the pregnancy."

In summary, this study has discovered the significant relationship between gender dynamics, power relations and decision-making regarding induced abortion among university undergraduate students in Nigeria.

\section{Discussion of findings and Recommendations}

The concept of power is an important concept to the social sciences. No discipline in the social sciences can successfully carry out its heuristic of researching the sources of social order without discussing who owns power, who benefits and who loses in the game of sharing the available power in society. The issue of power is very important because it explains the dynamics of social life; wealth, material wellbeing, gender, technology, governance, culture and other aspects of life. A man or woman without power is like a man or woman without wealth. Wealth distribution in modern society is largely a function of the class that people belong to and whether people will be asked to take decisions on the wealth that a society has is a function of the power they have capacity or potential to exert. No wonder, politics has been defined as "who gets what, when and how." It has also been defined as the "the authoritative allocation of values."

This study examined the nexus between gender dynamics, power relations and decision-making regarding induced abortion among undergraduate students of University of Lagos, Nigeria. Findings of the study revealed four dimensions of gender and power relations that have a significant impact on decision-making regarding induced abortion among students in the study location. The four essential forms of gender and power relations identified are: i.) Male-female power relations, ii.) Parent-child power relations, iii.) Significant order and power relations among peers, and iv.) Lecturer-student power relations. These four typologies of gender and power relations among other things promote a detrimental culture of clandestine and unsafe induced abortion among single young undergraduate students in Nigeria.

Due to the dominant power dynamics and gender relations in sexuality in the country, female vulnerability has been highlighted in a number of ways in this study: i) On account of their physiological constitution, even when they have protected sex, they are the only ones whose loss of virginity can be known; ii) the females sacrifice more to maintain a relationship than the males, e.g. they yield to sex sometimes without contraception - to please the males, and they may also abort a pregnancy out of consideration for his situation; iii) if they have unprotected sex, it is worse: as to keep or abort a pregnancy both carry possibly serious consequences. Sometimes, the females are even abandoned after a pregnancy/abortion.

Based on the findings of the study, there is a need to strengthen the existing structure that promotes gender equality in the country. In addition, young female students that are sexually active should be 
empowered to adopt efficient and effective contraception. Furthermore, there is a need to build the capacity of Nigerian female undergraduate students especially in the areas of self-dignity and selfesteem in order for them to take right decisions whenever an unwanted pregnancy occurs. Finally, there is an urgent need to educate male partners of undergraduate female students about the need to provide their female sexual partners with adequate support whenever an unwanted pregnancy occurs, in abortion decision-making and dealing with its associated consequences. Research shows that where such support is provided, the issue of abortion may not be an option and whenever it is necessary; women tend to have safe abortions and are able to cope better with the consequences of abortion.

\section{References}

Alubo, O. (1990). "Doctoring as Business: A study of Entrepreneurial Medicine in Nigeria." Medical Anthropology, 12:305-324.

Aniekwu, N. (2003). "Abortion and reproductive rights in Nigeria - A review of criminal laws and legislative policies." Annals of Biomedical Sciences, College of Medicine. University of Benin, Nigeria. 2(I): I-I0.

Bankole, A., Singh, S. \& Haas, T. (1999). Characteristics of women who obtain induced abortion: A worldwide review. International Family Planning Perspectives 25(2):68-77.

Bankole, A., Sedgh, G., Oye-Adeniran, B.A., Adewole, I.F., Hussain, R., \& Singh, S. (2004). "Abortion seeking behaviour among Nigerian women." Paper presented at the annual meeting of the Population Association of America, Boston, MA, USA, April I-3, 2004.

Bankole, A., Oye-Adeniran, B. A., Singh, S., Adewole, I. F., Wulf, D., Sedgh, G. \& Hussain, R. (2006). Unwanted pregnancy and induced abortion in Nigeria: Causes and consequences. The Alan Guttmacher Institute (AGI), New York.

Bankole, A., Adewole, I. F., Hussain, R., Awolude, O., Singh, S., \& Akinyemi, J.O. (2015). The Incidence of Abortion in Nigeria. International Perspective on Sexual and Reproductive Health 4I(4): I70181 .

Biddlecom, A., Awusabo-Asare, K., \& Bankole, A. (2009). Role of Parents in Adolescent Sexual Activity and Contraceptive Use in Four African Countries. International Perspective on Sexual and Reproductive Health 35(2):72-8I.

Foucault, M. (1991). Discipline and Punish: the birth of a prison. London: Penguin.

Foucault, M. (1998). The History of Sexuality: The Will to Knowledge, London: Penguin.
Gaventa, J. (2003) Power after Lukes: a review of the literature, Brighton: Institute of Development Studies.

Haralambos, M. \& R. Heald (I 980). Sociology: Theme and Perspectives. Slough (U.K): University Press Limited.

Makinwa-Adebusoye, P., Singh, S. \& Audam, S. (1997). Nigerian Health Professionals' Perceptions about Abortion Practice. International Family Planning Perspectives. 24(4): I55-I6I.

Olukoya, A. A., Kaya, A., Ferguson, B. J. \& AbouZahr, C. (200I). "Unsafe abortion in adolescents." International Journal of Gynecology and Obstetrics, 75(2): I37-I 47.

Oyefara, J.L. (20/2). "Social Dynamics of HIV/AIDS Epidemiology and Potential for Escalation in Delta State, Nigeria". British Journal of Arts and Social Sciences. 7 (I): 63-8I.

Oyefara, J.L. (2016). "Sexual Behaviour, Unwanted Pregnancy and Tripartite Levels of Decisionmaking regarding Induced Abortion among Nigerian University Students." African Journal for Psychological and Social Sciences Issues, 19(3): 6I86.

Post Abortion Care Consortium Community Task Force. [PAC] (2002). Essential Elements of Post abortion Care: An Expanded and Updated Model. USA: PAC.

Rabinow, P. (ed.) (1991). The Foucault Reader: An introduction to Foucault's thought, London, Penguin.

Sedgh, G., Bearak, J., Singh, S., Bankole, A., Popinchalk, A., Ganatra, B., Rossier, C., Gerdts, C., Tuncalp, O., Johnson, B.R. Jr., Johnston, H.B., and Alkema, L. (20/6). Abortion Incidence between 1990 and 2014: Global, regional, and subregional levels and trends. The Lancet 388(I004I):258-267.

Sule-Odu, A. O., Olatunji, A. O. \& Akindele, R. A. (2002). "Complicated induced abortion in Sagamu, Nigeria". Journal of Obstetrics and Gynaecology. 22 (I):56-6I.

World Health Organization [WHO] (2004). Prevention of unsafe abortion: The persistent public health problem. Retrieved from http://www.who.int/reproductivehealth/unsafe_ab ortion/index.html, August, 2016. 